\title{
KORELASI ANTARA ETIKA DENGAN ETOS KERJA PENDIDIK PAUD
}

\author{
NURAENI \\ FIPP Universitas Pendidikan Mandalika \\ Email: nuraeni@undikma.ac.id
}

\begin{abstract}
The purpose of this study was to determine the correlation between ethics and the work ethic of PAUD educators. In this study the approach used is quantitative correlation. The sample in this study amounted to 20 PAUD teachers spread across the city of Mataram. The data collection method used is an attitude scale that includes ethics and work ethic which was developed based on the indicators of each research variable. Data analysis using SPSS Pearson Bivariate Correlation. Based on the results of data analysis, it can be concluded that ethics is significantly correlated with the work ethic behavior of PAUD educators in Mataram City.
\end{abstract}

Keywords: Ethics, work ethic, PAUD educators

\begin{abstract}
ABSTRAK
Tujuan dalam penelitian ini adalah untuk mengetahui korelasi antara etika dengan etos kerja pendidik PAUD. Dalam penelitian ini pendekatan yang digunakan adalah kuantitatif korelasional. Sampel dalam penelitian ini berjumlah 20 orang guru PAUD yang tersebar di Kota Mataram. Metode pengumpulan data yang digunakan adalah berupa skala sikap yang mencakup etika dan etos kerja yang dikembangkan berdasarkan indikator dari masing-masing variabel penelitian. Analisis data menggunakan bantuan SPSS korelasi Bivariat Pearson. Bedasarkan hasil analisis data maka dapat disimpulkan bahwa etika berkorelasi signifikan terhadap perilaku etos kerja pendidik PAUD di Kota Mataram.
\end{abstract}

Kata kunci: Etika, etos kerja, pendidik PAUD

\section{PENDAHULUAN}

Etika sangat penting bagi pendidik yang berperan sebagai pembimbing, pembina perilaku, dan sekaligus model berperilaku manusia beretika karena ini bagian dari tanggung jawab sebagai pendidik. Etika yang diajarkan dan diaplikasikan secara terus-menerus merupakan salah satu landasan untuk terbentuknya kepribadian individu. Kepribadian, menurut Allport (dalam Wortman, Camille, Loftus \& Weaver, 2000) adalah organisasi dinamis di dalam individu yang terdiri dari sistem-sistem psikofisik yang menentukan tingkah-laku dan pikirannya secara karakteristik dalam menyesuaikan diri terhadap lingkungan. Kepribadian selalu berkembang dan berubah meskipun ada suatu sistem organisasi yang mengikat dan menghubungkan berbagai komponen dari kepribadian kita. Kepribadian melingkupi kerja tubuh dan jiwa (tak terpisahkan) dalam satu kesatuan yang mengandung kecenderungankecenderungan dalam tingkah laku individu. Kepribadian sifatnya individual karena tidak ada orang yang memiliki kesamaan dalam upaya menyesuaikan diri dengan lingkungannya. Oleh sebab itu, kepribadian membedakan individu. Dalam perjalanannya, kepribadian seseorang berhadapan dengan lingkungannya yang turut membentuknya hingga mencapai taraf kematangan tertentu.

Kepribadian juga terkait dengan etos. Etos berasal dari bahasa Yunani "ethos" yang berarti sikap, kepribadian, watak, karakter, serta keyakinan atas sesuatu (Jansen, 2010). Sikap ini tidak saja dimiliki oleh individu, tetapi juga oleh kelompok bahkan masyarakat yang dapat membedakan satu kelompok dengan kelompok atau masyarakat lain. Oleh sebab itu, etos berkaitan dengan kebudayaan suatu kelompok masyarakat. Etos merupakan produk dari sistem kepercayaan yang diterima seseorang atau kelompok atau masyarakat. Setiap pendidik haruslah terus-menerus membangun etos keguruannya agar akhirnya ia bisa menjadi guru atau pendidik yang terbaik. Etos kerja yaitu semua kebiasaan baik yang harus dilakukan di tempat kerja. Ada delapan kebiasaan bekerja cerdas yang dapat menjadi landasan etos kerja positif bagi para 
pendidik PAUD. Delapan kebiasaan dalam etos kerja positif menurut Jansen (2010) adalah: (1) bekerja ikhlas; (2) bekerja penuh rasa syukur; (3) bekerja penuh integitas; (4) bekerja keras penuh semangat; (5) bekerja serius penuh kecintaan; (6) bekerja cerdas penuh kreativitas; (7) bekerja tekun penuh keunggulan; dan (8) bekerja paripurna penuh kesabaran.

Selain delapan etos kerja tersebut, dikenal pula etos kerja berlandasan spiritual yang dapat dikembangkan lagi oleh guru dan implementasikannya dalam kehidupan sehari-hari, yakni Etos kerja sebagai mental rohani. Menurut Pudjijogyanti (1988) tugas sebagai guru dapat dilihat dari segi mental rohani, agar didapatkan kepuasan kerja. Tanpa etos kerja yang tinggi, seorang pendidik tidak mungkin dapat meningkatkan produktivitas mengajarnya seperti apa yang diharapkan. Upaya menumbuhkan etos kerja yang positif tidak dapat dipaksakan karena dalam menumbuhkan etos kerja diperlukan kolaborasi dan keselarasan relasi antara individu di dalam suatu komunitas pendidikan, dalam hal ini PAUD.

Pendidik, secara spesifik "guru", oleh Macmillan (dalam Dani, 2005) didefinisikan sebagai seorang yang dihormati dan tempat meminta nasihat untuk permasalahan-permasalahan tertentu. Guru merupakan seorang yang mengajar dengan hatinya, membimbing dengan nuraninya, mendidik dengan segenap keihklasan dan menginspirasi dan menyampaikan kebenaran dengan rasa kasih. Oleh sebab itu, penting bagi seorang pendidik PAUD untuk memiliki kepribadian atau etos yang positif. Secara umum, menurut Rusyan (dalam Zahara \& Jamal, 1992) kepribadian atau etos penting bagi para profesional, antara lain pendidik, sebagai: (1) pendorong timbulnya perbuatan, (2) penggairah dalam aktivitas, dan (3) penggerak yang menentukan cepat atau lambatnya suatu perbuatan.

Orang yang bekerja di lingkungan pendidikan, pendidik dan tenaga kependidikan, seharusnya tidak hanya melihat pekerjaannya sebagai tempat mencari nafkah. la harus melihatnya sebagai tugas yang mengemban esensi pendidikan. Menurut Isjoni dan Suarman (2003) pendidikan itu bukan hanya untuk hari ini dan esok, melainkan membangun kehidupan jauh ke depan. Esensi pendidikan dalam hal ini bagaimana mencerdaskan SDM, masyarakat dan bangsa, sehingga mampu beradaptasi sekaligus melakukan pembaharuan dalam kehidupannya.

Guru yang berkualitas akan terbentuk jika memiliki kepribadian dan etos kerja yang tinggi. Menurut Jansen Sinamo ada delapan etos kerja unggulan yang perlu dipahami, yang dapat dikembangkan oleh guru dalam bertugas. Etos kerja tersebut sebagai berikut: (1) kerja itu suci, kerja adalah panggilan ku, aku sanggup bekerja benar; (2) kerja itu sehat, kerja adalah aktualisasiku, aku sanggup bekerja keras; (3) kerja itu rahmat, kerja adalah terima kasihku, aku sanggup bekerja tulus; (4) kerja itu amanah, kerja itu tanggungjawabku, aku sanggup bekerja tuntas; (5) kerja itu seni atau permainan, kerja adalah kesukaanku, aku sanggup kerja kreatif; (6) kerja itu ibadah, kerja adalah pengabdianku, aku sanggup bekerja serius; (7) kerja itu mulia, kerja adalah pelayananku, aku sanggup bekerja sempurna; dan (8) kerja itu kehormatan, kerja adalah kewajibanku, aku sanggup bekerja unggul.

Adapun untuk mencapai perubahan dan perbaikan di bidang pendidikan, dalam rangka melahirkan sebuah generasi yang berkualitas, berintegritas, memiliki karakter, dan menjunjung tinggi nilai-nilai moral, tentu saja masih banyak hal lain yang perlu dicermati. Banyak butir kebijaksanaan (wisdom) yang perlu kita ketahui, pelajari, dan aplikasikan dalam kehidupan nyata. Hal ini tentunya untuk dapat mengasah kepribadian unggul yang dimiliki setiap individu, khususnya pada pendidik PAUD. Setiap pendidik, khususnya pendidik PAUD, perlu untuk mengembangkan beberapa kepribadian unggul sehingga hasil pembelajaran dapat dicapai secara maksimal.

\section{METODE PENELITIAN}

Dalam penelitian ini pendekatan yang digunakan adalah kuantitatif korelasional yang bertujuan untuk menguji apakah etika dapat mempengaruhi etos kerja guru PAUD. Subyek dalam penelitian ini sebanyak 20 orang guru PAUD yang tersebar di kota Mataram. Data dikumpulkan menggunakan instrument skala sikap etika dan etos kerja. Adapun instrument ini 
dikembangkan sendiri oleh peneliti berdasarkan indikatornya. Lebih lanjut untuk analisis data menggunakan bantuan SPSS korelasi Bivariat Pearson. Adapun instrument yang digunakan dalam penelitian ini sama-sama memiliki 20 item pernyataan dengan menggunakan skala Likert 4 kriteria pilihan yaitu: Sangat Setuju, Kurang Setuju (KS), Tidak Setuju (TS) dan Sangat Tidak Setuju (STS).

\section{HASIL DAN PEMBAHASAN}

Berdasarkan analisis data yang sudah dilakukan, menunjukkan bahwa terdapat hubungan yang signifikan antara etika dengan etos kerja yang ditunjukkan oleh $p$-value sebesar $0.000<0.001$ dan nilai t-hitung $0.545>\mathrm{t}$-tabel 0.444 . Lebih lanjut hasil penelitian ini menunjukkan bahwa besaran pengaruh etika terhadap etos kerja yaitu sebesar $54.5 \%$.

Tabel 1. Hasil SPSS Uji Korelasi Bivariat Pearson

\begin{tabular}{|c|c|c|c|}
\hline & & Etika & Etos Kerja \\
\hline \multirow{3}{*}{ Empati } & Pearson Correlation & 1 & $.545^{* *}$ \\
\hline & Sig. (2-tailed) & & .013 \\
\hline & $\mathrm{N}$ & 20 & 20 \\
\hline \multirow{3}{*}{ Cyberbullying } & Pearson Correlation & $.545^{* *}$ & 1 \\
\hline & Sig. (2-tailed) & .013 & \\
\hline & $\mathrm{N}$ & 20 & 20 \\
\hline
\end{tabular}

Dalam penelitian ini ada beberapa kepribadian unggul yang dapat dikembangkan oleh pendidik PAUD: (1) Kreatif, dimana pada dasarnya potensi kreatif dimiliki oleh setiap individu, namun tingkat dan derajatnya yang berbeda-beda antar individu yang satu dan lainnya. Hal ini dipengaruhi berbagai faktor baik internal dan eksternal. Seseorang dengan potensi kreativitas yang tinggi dan memiliki lingkungan yang memberi kesempatan secara bebas dan aman psikologis akan menjadikan orang tersebut sebagai pribadi yang kreatif. Menurut Michael A. West, seperti yang dikutip oleh Antonius dkk, (2002) menyatakan kreativitas sebagai pernyataan pengetahuan dari berbagai bidang pengalaman yang berkaitan untuk menghasilkan ide-ide baru yang lebih baik. Kreativitas merupakan salah satu bagian mendasar dari usaha manusia. Kreativitas melibatkan kita dalam penemuan-penemuan yang terus menerus dengan cara yang baru dan lebih baik dalam mengerjakan berbagai hal. Lebih lanjut diuraikan bahwa kreativitas merupakan kemampuan seseorang untuk melahirkan suatu gagasan baru maupun karya nyata atau kombinasi dengan hal-hal yang sudah ada sehingga relatif berbeda dengan yang ada sebelumnya.

Menjadi pribadi yang kreatif sangat penting bagi pendidik PAUD karena setiap hari berhadapan dengan anak mengharuskan para pendidik harus selalu kreatif memikirkan materi dan aktivitas yang akan diberikan serta memodifikasi alat belajar maupun alat permainan. Terlebih bagi pendidik PAUD yang berada di wilayah minim fasilitas, kreativitas menjadi salah satu kualitas pribadi unggul yang harus dimiliki sehingga pendidik dapat memberdayakan seluruh potensi di sekitarnya agar dapat menciptakan pembelajaran yang menyenangkan dan bermakna bagi anak.

Selanjutnya (2) Afektif, di mana Siswa PAUD memiliki karakteristik yang khas dan berbeda dengan peserta didik dalam jenjang pendidikan lainnya. Dalam proses belajarnya, siswa PAUD membutuhkan perhatian khusus dari para pendidik dimana perhatian dan respon positif yang ditunjukkan pendidik kepada siswa akan menstimulasi siswa secara positif pula dan potensinya akan berkembang maksimal. Menurut tahap perkembangan psikososial Erik Erikson (dalam Wortman, Loftus \& Weaver, 2000) anak usia dini dapat diklasifikasikan ke dalam tahap initiative versus guilt atau tahapan ketiga dari delapan tahapan perkembangan 
psikososial Erikson. Pada tahap ini anak akan memiliki inisiatif untuk melakukan atau mempelajari hal-hal dan aktivitas baru sehingga perhatian atau afeksi yang memadai dari para pendidik sangat diperlukan agar anak merasa diperhatikan dan mendapat dukungan dari pendidik sebagai orang dewasa yang berpengaruh (significant others). Minimnya perhatian pendidik atas inisiatif siswa PAUD atau pemberian respon yang salah akan berakibat pada munculnya rasa bersalah (guilt) yang tentunya beek negatif bagi perkembangan anak selanjutnya.

Untuk dapat mengasah sikap afektif sebagai bagian dari pribadi unggul pendidik PAUD, maka sebelumnya perlu diketahui ciri-ciri sikap afektif. Ciri-ciri sikap afektif antara lain ditunjukkan dengan sikap sebagai berikut: (1) rasa ingin tahu; selalu terdorong untuk mengetahui/bertanya lebih banyak, selalu memperhatikan orang, objek dan situasi, peka dalam pengamatan dan ingin mengetahui dan meneliti; (2) Bersifat imajinatif; mampu memperagakan atau membayangkan hal-hal yang belum pernah terjadi, menggunakan imajinasi; (3) merasa tertantang; terdorong untuk mengatasi masalah dan tertantang pada situasi yang sulit, lebih tertarik pada tugas-tugaas yang sulit; (4) berani mengambil resiko; berani memberikan jawaban apa adanya, tidak takut gagal atau mendapat kritik; dan (5) sifat menghargai; memberikan apresiasi pada diri sendiri dan orang lain dalam berbagai keadaan.

Adapun yang (3) Mandiri, di mana kemandirian berhubungan dengan manusia yang sedang melaksanakan kegiatan tersendiri atau bekerja yang tidak secara langsung melibatkan orang lain. Hal tersebut seperti yang dikemukakan Antonius dkk (2002) mandiri adalah suatu suasana di mana seseorang mau dan mampu mewujudkan kehendak atau keinginan dirinya yang terlihat dari tindakan atau perbuatan nyata guna menghasilkan sesuatu (barang atau jasa) demi pemenuhan kebutuhan hidupnya dan sesamanya. Mandiri sebagai suatu sikap mental berarti kesiapan seseorang untuk mengembangkan diri dengan kekuatan sendiri.

Hal ini tidak berarti kita menutup diri dari pengaruh orang lain atau sesama. Kemandirian berbeda dengan sikap mental egois dan individualistik yang mengutamakan kepentingan diri sendiri dan tidak mempedulikan kepentingan sesama. Kemandirian memiliki makna bahwa dalam proses mengenal-menerima dan mengembangkan diri tidak mengantungkan diri pada orang lain. Seseorang menjadi independen bukan dependen, namun tetap membangun hubungan sosial dengan sesama manusia. Konsep mengenai kemandirian sendiri mencakup di dalamnya sikap tanggung jawab, khususnya tanggung jawab atas apa yang dilakukan tanpa membebani orang lain.

Sedangkan di dalam penelitian ini membangun etos keguruan sesungguhnya juga serentak membangun karakter para guru karena, ibarat otot, karakter akan memadat dengan semakin kokohnya sebuah perilaku karena terus menerus digunakan secara tekun dan bertujuan. Inilah makna yang terkandung dalam definisi karakter dalam kamus, yaitu kualitas-kualitas mental dan moral yang khusus dan khas pada individu, kelompok, atau institusi.

Kompetensi, yaitu keterampilan atau pengetahuan yang diperlukan agar mampu melakukan sesuatu secara berhasil juga semakin bagus karena beretos kerja tidak lain berarti melaksanakan proses aktualisasi diri secara swakarsa,secara konkret melalui serangkaian perbuatan dan tidakan yang ajek sehingga mutu kompetensi itu semakin baik pula; seperti misalnya saja: etos ketekunan dalam menulis pastilah meningkatkan kompetensi kita dalam berbahasa dan berpikir.

Khusus untuk guru dan dosen, kini undang-undang bahkan menuntut kita untuk memiliki setidaknya empat kompetensi yang bermutu tinggi: personal, profesional, pedagogik, dan sosial. Demikian pula di dalam Peraturan Menteri Pendidikan Nasional No. 137 tahun 2014 terdapat empat kompetensi pendidik PAUD, yaitu: (1) Kompetensi Pedagogik, yang merupakan kemampuan mengelola peserta didik yang meliputi pemahaman terhadap peserta didik, perancangan dan pelaksanaan pembelajaran, evaluasi hasil belajar, serta pengembangan peserta didik untuk mengaktualisasikan berbagai potensi yang dimiliki; (2) Mengorganisasikan aspek perkembangan sesuai dengan karakteristik anak usia dini; (3) Menganalisis teori bermain sesuai aspek dan tahapan perkembangan, kebutuhan, potensi, bakat, dan minat anak usia dini; (4) 
Merancang kegiatan pengembangan anak usia dini berdasarkan kurikulum; (5) Menyelenggarakan kegiatan pengembangan yang mendidik; (6) Memanfaatkan teknologi, informasi dan komunikasi untuk kepentingan penyelenggaraan kegiatan pengembangan yang mendidik; (7) Mengembangkan potensi anak usia dini untuk pengaktualisasian diri; (8) Berkomunikasi secara efektif, empatik, dan santun; (9) Menyelenggarakan dan membuat laporan penilaian, evaluasi proses dan hasil belajar anak usia dini; (10) Menentukan lingkup sasaran asesmen proses dan hasil pembelajaran pada anak usia dini; dan (11) Menggunakan hasil penilaian, pengembangan dan evaluasi program untuk kepentingan pengembangan anak usia dini.

Setelah elemen perencanaan terpenuhi, maka kompetensi untuk melaksanakan proses pendidikan, pengasuhan, dan perlindungan juga adalah poin penting yang harus dimiliki guru atau pendidik PAUD. Yang termasuk aspek pelaksanaan dalam kompetensi pedagogik pendidik PAUD antara lain: (1) Mengelola kegiatan sesuai dengan rencana yang disusun berdasarkan kelompok usia; (2) Menggunakan metode pembelajaran melalui bermain sesuai dengan karakteristik anak; (3) Memilih dan menggunakan media yang sesuai dengan kegiatan dan kondisi anak; (4) Memberikan motivasi untuk meningkatkan keterlibatan anak dalam kegiatan; dan (5) Memberikan bimbingan sesuai dengan kebutuhan anak.

\section{KESIMPULAN}

Berdasarkan hasil penelitian yang sudah diperoleh maka dapat disimpulkan, etika yang baik berkorelasi terhadap terjadinya peningkatan etos kerja. Adapun di dalam penelitian ini, etika yang baik dapat digunakan menjadi solusi yang positif untuk meningkatkanetos kerja guru PAUD di Kota Mataram. Untuk memiliki etika yang baik maka siswa dapat diberikan pelatihan menjadi seorang guru yang professional dan beretika positif dengan menggunakan teknikteknik atau pendekatan yang sesuai. Penelitian ini terbatas hanya untuk melihat korelasi antara etika dengan etos kerja, sehingga bagi peneliti selanjutnya dapat meneliti etika dan etos kerja guru PAUD yang di tinjau dari aspek yang berbeda.

\section{DAFTAR PUSTAKA}

Diaz, Carlos F. et al. (2006). Touch The Future Teach!. USA: Pearson Education.

Direktorat Pendidikan Anak Usia Dini Dirjen Pendidikan Nonformal dan Informal Kemendiknas. (2010). Peraturan Menteri Pendidikan Nasional tentang Standar Pendidikan Anak Usia Dini. Jakarta: Direktorat Pendidikan Anak Usia Dini.

Gea, Antonius Atosokhi, Antonina Panca Yuni Wulandari, Yohanes Babari. (2002). Relasi dengan Diri Sendiri. Jakarta: Elex Media Komputindo.

Idris, H. Zahara \& H. Lisma Jamal. (1992). Pengantar Pendidikan 1. Jakarta : Grasindo.

Morrison, George. (2007). Early Childhood Education Today. Columbus Ohio: PearsonPrentice Hall.

Pudjijogyanti, Clara R. (1988). Konsep Diri Dalam Pendidikan. Jakarta: Arcan.

Ronnie M., Dani. (2005). Seni Mengajar Dengan Hati. Jakarata: Elex Media Komputindo Sinarmo, Jansen. (2010). Delapan Etos Kerja Keguruan. Jakarta: Institut Darma Mahardika. Wortman, Camille, Loftus \& Weaver. (2000). Psychology. USA: McGraw-Hill. 